\title{
Philosophical Tenets of Action Research in Education ?
}

Luis Sebastián Villacañas de Castro, Universitat de València

and Darío Luis Banegas, University of Warwick

https://doi.org/10.1093/acrefore/9780190264093.013.1429

Published online: 27 October 2020

\section{Summary}

The juxtaposition of action and research conveys a sense of the richness and complexity of action research, yet it does not entirely translate its nuanced and sophisticated philosophy. In turn, an understanding of this philosophy is crucial for grasping action research's radical originality. In this context at least, it may be more accurate to define action research by drawing on the term practice, even though it does not form part of the basic conceptual pair. Not only does practice make it easier for us to trace the constellation of philosophical influences behind the theory and practice of action research-from pragmatism to postmodernism, including Greek philosophy and Marxist and psychoanalytic schools of thought-but also to identify where these influences end and action research emerges as the bearer of a nontransferable view. Beyond this, at the heart of action research lies a structural affinity with singular social practices, which are its key ontological sites-that is, the context where action research in each case fills its epistemological and ethical dimensions with meaning.

What kind of knowledge does action research aim to produce? What behaviors do action researchers engage in? Compared to other research paradigms in the social sciencesthe field of education included-the specific quality of action research has to do with how its epistemological and ethical dimensions are shaped not from without but from within any given social practice. This is the key to its specific ecology. In action research, the epistemological and ethical realms do not stand beyond or above the situated social practices, with their values, principles of procedure, knowledges, and discourses, including their own literacies and modalities-in short, their own internal cultures. Action research conceives and presents itself as a rational and systematic way for members of the different social practices to build and rebuild their own epistemologies and ethics precisely by drawing on, and selecting from, their own internal cultures.

How does this ecological perspective translate itself in education? Education is one of the key areas in which action research is generally applied, together with welfare and healthcare. Yet apart from the specific use of action research by educators, action research carries within itself a specific educational philosophy (and a political philosophy as well) which underlies its application, regardless of the specific social practice in which it takes place. In the same way that action research is politically democratic, educationally speaking action research is participatory, meaning that learning, improvement, or development can only be realized through a self-determining process in which people act and research freely upon and among themselves. This is precisely what action research facilitates in the different social practices. Action research is always educational, whether one develops it in education, welfare, or healthcare. As a result, 
action research has contributed a clear-cut pedagogical model that some critical educators have already imported to their own educational institutions and practices: youth participatory action research.

Keywords: educational action research, philosophies of action research, epistemologies of action research, methodologies of action research, ethics of action research, social practices

\section{Introduction}

The philosophical roots of action research are deep and robust. Pragmatism, ancient Greek philosophy, psychoanalysis, postmodernism, and even Marxist schools of thought are recurrently mentioned in historical reconstructions of action research (Adelman, 1993; Boog, 2003; Burns, 2005; Côte-Thibault, 1996; Greenwood, 2015; McTaggart, 1991), so one could rightly expect action research literature to engage in philosophical registers. Next to a majority of case studies covering social practices (mainly education, healthcare, and social welfare) action researchers have also cultivated philosophical reflections to better define general and particular aspects of action research from epistemological, methodological, ethical, political, or pedagogical points of view. In turn, these reflections have usually been framed within debates around the specific quality of action research, around what distinguishes it not only from dominant, positivist views of scientific research but also from a family of approaches with which it is often conflated (Brydon-Miller, Greenwood, \& Maguire, 2003; Dick, 2004; Fine, 2008). As occurs with the many philosophical traditions that nourish it, eclecticism is an ingrained quality of action research, which is either favored and welcomed or fought and warned against with equal intensity (Katsarou, 2017). One could conclude from the literature that action research is too narrow and too loose at the same time.

Philosophical reflections on action research have often focused on the specific equilibrium, relationship, and realities behind "action" and "research" (Hammersley, 2004). This article also starts with these two concepts, but it soon identifies the term social practice to convey what action research represents. By bringing "social practice" within the vicinity of other terms such as democracy, emancipation, and pedagogy, we offer a philosophical reconstruction of action research that leaves no stone unturned and taps into its manifold dimensions. The strengths and weaknesses of action research-its unity as much as its internal diversity, the centripetal as much as the centrifugal forces that shape it-are an expression of the fundamental move through which research becomes rooted in specific social practices like education. This is the key ontological tenet of action research, while the epistemological, methodological, and practical instantiations carried out by action researchers are the substance that give it content. The synchronic and diachronic diversity of action research results from having "social practices" at its ontological foundation and is, therefore, a manifestation of the partial ability of this concept to hold the paradigm together in a balance that is clearly imperfect and unstable, and which nourishes innovation and creativity as much as it raises tensions. The first sections of this article focus on the transition undergone by 
action research, from considering "action" its key concept to replacing "action" with a growing emphasis on "social practices," while the remaining sections describe the consequences that derive from that ontological move.

The resulting argument is philosophical, not because it focuses on the philosophical beliefs or traditions behind the many ways in which action research has been, and still is, theorized and practiced in history and throughout the world but, rather because, through its different sections, the text takes every effort to explain how action research structures itself in a coherent way across the ontological, epistemological, methodological, ethical, political, and pedagogical planes. This article clearly adopts a different approach from those through which action research has often been examined. Instead of dividing its panorama into technical, practical, and critical forms of action research (Burns, 2005) or other distinctions and subdomains, this article suggests, first, that there is an internal logic to action research andsecond-that it is only by tracing this logic as it unfolds through the above-mentioned ontological, epistemological, methodological, ethical, political, and pedagogical planes that the logic and concept of action research can be brought full circle and understood for all its democratic quality and potential. This is the core idea, although the latter will also point out the weaker links in the action research framework-precisely where the pull of the different philosophical traditions risk breaking the unitary chain.

"Action and Research" and "Social Practice and Research" are the first two sections; then various other sections offer an interpretation of the alternating emphasis that different schools of action research have placed on either action or social practice as the key units shaping its ontology, epistemology, methodology, ethics, and politics. This difference is read in terms of a transition from the limitations of the naturalistic approach to those of the sociocultural one, which coincided with a gradual enrichment of the original pragmatist influence in action research with other sociological and humanistic perspectives. In the naturalistic approach, action was a testable unit that enabled inquiry into one's experimental relationship with the world. As shown in the section "Epistemology, Methodology, and Ethics of Action Research," through the transition toward a sociocultural perspective, the corresponding notions of action and research were refined but also made more problematic, as its epistemological and methodological components were forced to interact with a plurality of demands pertaining to each social practice. Ideally, the section "Educational Action Research" will illustrate this point through specific examples. Once action research is thus firmly grounded on specific social practices, the section "Social Practice, Democracy, and Action Research" will set out to address the political dimension of action research, and to reveal how the logical connection holding together the three terms in this subtitle is less consistent than is frequently acknowledged in theory or proven by practice. At this point in the argument, the Marxist reading of democracy will be used to identify, through contrast, the real contours of the democratic and transformative options that action research has at hand. Ultimately, the concluding section, "Action Research and Pedagogy," will offer a reformulation of many of the concepts and qualities covered in earlier sections from the perspective of the pedagogical rationality of action research. From this angle, one of the main contributions of action research to teaching methodology-youth participatory action research-will be understood and justified as a striking synthesis of action research, democracy, and education, at the same time being a mirror in which each of them, separately, can see their best realization. 


\section{Action and Research}

Possibly led by the need to understand action research internally and externally, one of the ways in which its two components have been articulated has been by claiming that action research is research conducted on actions. Actions would be the basic matter of inquiry. "Action research," Coghlan and Shani (2005) said, "is about undertaking action and studying action as it takes place" (p. 533), while Dick (2015) insisted that "the understanding generated by action research is from action and for action" (p. 437). Even when action research found inspiration in psychoanalysis (Carson, 2009), as it did in the work of Jacob Levi Moreno (1940), it did so by resorting to the activist strand represented by his psychodrama (see Greenberg, 1974) in which patients' acting out in a safe environment (and ulterior collective reflection) became the key therapeutic method (Boog, 1989) as opposed to Freudian free association. Through this action turn (Ospina \& Anderson, 2014), action research decidedly separated itself from positivist research in the natural or social sciences. In contrast to phenomena, actions are purposeful and respond to aims that may or may not be realized but to whose attainment action research commits itself. Among other factors, success depends on the amount of knowledge obtained from the environment in which the given action is bound to take place-on "diagnosis," as Lewin (1946, p. 37) called it in his seminal work.

One can trace the influence of empiricist (i.e., less sociocultural) and naturalistic (i.e., less historical) strands of North American pragmatism in these initial conceptions. Historical and philosophical accounts of action research in the literature, for example, often insist on the influence of John Dewey's work in shaping the paradigm (Harkavy \& Puckett, 2014; Stark, 2014). Indeed, action also holds a prominent place in his interactionist ontology and epistemology built around the concept of inquiry. For Dewey (1938), thought and action were a response to the changing needs experienced by the individual in relation to the everchanging demands of the environment with which the individual by necessity interacted. Action was the key experimental variable in one's daily interaction with the world, but in no way was thought an autonomous faculty, residing on a different plane from action; rather, it insisted on and extended the material rapport occurring between the individual and the environment (Miettinen, 2000). Accordingly, scientific research was simply the most rational, technical, and thus transformative manifestation (since it employed the most developed sets of signs and tools) of human inquiry understood as a way of being in the world.

In this paradigm, the uses of "action" and "environment" remained somewhat general and abstract, although this did not prevent interesting developments. Chris Argyris's work possibly represents the most sophisticated example of this action perspective, which he enhanced, radicalized, and systematized in his ambitious conception of an action science (Argyris, Putnam, \& McLain Smith, 1985). Drawing on Dewey and Lewin's work, Argyris gave action research a scientific legitimization of its own, distinct from positivist understandings of validity. First, Argyris insisted on the common emergence of everyday and scientific inquiry in the needs and demands of environmental contexts. Premised on this ontological fact, he then derived the need to devise a style of scientific research in which action remained the key epistemological and methodological unit. This meant, in his terms (Argyris, 1997), that action science had to operate with hypotheses and methods that were fully "actionable," which is what testability meant from an action perspective. Accordingly, hypotheses had to be formulated in terms of causal statements that could be tested "by anyone, under real time, 
everyday life conditions," by assessing the effects of clear-cut, well-defined action hypotheses. Second, the knowledge that was generated also needed to be "user-friendly" - a reformulation of the generalizability/transferability principle-meaning that its validity, if confirmed, should allow other individuals to apply it to their own contexts and conduct their own effective actions (Argyris, 1997, pp. 812-816).

Another key trait in Argyris's work was his insistence, along the lines of Lewin (1946), not only on the general validity of research conducted through actions but especially on the validity of research conducted through actions aimed at transforming the world. His argument remains compelling for action researchers working in this tradition long after Argyris's day. According to him, it was only research whose actionable and transformative hypotheses were ultimately confirmed that evinced the kind of understanding of reality that was compatible with a strong notion of causality. Actionability and causality-the validity criteria of scientific rigor-were best fulfilled by actionable hypotheses that succeeded in bringing "rare events," or novelty, to the world (Argyris, 1997). With this argument, Argyris consummated his charges against postmodernism and positivism alike, to the extent that they both questioned a strong notion of causality. Regarding positivism, he identified its heuristic limitations in how it need not understand the world in order to predict it, precisely because it only tried to predict what, on account of the status quo, was probably bound to happen anyway. For action science, "creating, not predicting, [was] the most robust test of validity-actionability" (p. 817; see also Gergen \& Gergen, 2008). Conversely, the noncausal, nonactionable, and user-unfriendly character of positivist multivariate statistics did not prevent scientists from succeeding (most of the time) in predicting the future developments of an obscure inertia, the causal depths of which they remained no less blind to at the end of the day. In other words, acting against the superficial and complicit insight of positivism, action scientists should generate knowledge that was right because it proved capable of transforming reality, of pushing it in novel directions that, if left to itself, reality would likely not have taken.

\section{Social Practice and Research}

The articulation of action and research in Dewey's and Argyris's work provided robust philosophical tenets for action research to stand on its own feet. Nevertheless, this section hypothesizes that to the extent that both contributions remained tied to the individualenvironmental dyad, they also limited action research theory and practice, motivating alternative developments and responses. Ulterior trajectories of action research reoriented themselves toward sociocultural ontologies and epistemologies which, rather than dissolving the focus on action, enriched its understanding by contextualizing it within determinate social practices. "Recent thinking about action research," argued Kemmis (2008), "gives increasing emphasis to the social" (p. 122). Paradoxically, through this social move, these contributions also revealed dimensions that were already present in the work of Dewey (1916) and Argyris, despite not having found their most adequate conceptual scope or means of expression. Apart from Deweyan philosophy, Weberian social ontology left its indelible mark, especially for acknowledging the autonomy and plurality of social spheres, each with its own ethos and corresponding human ideal types (Weber, 1946). Finally, another major influence in the definition of the sociocultural turn of action research was ancient Greek philosophy. Especially relevant for educational action research was Aristotle's phronesis-at least for the school founded around the Centre of Applied Research in Education in the University of East Anglia 
(Norris, 2012) - a practical philosophy whose interests lay in exploring how the idea of good could be realized in concrete human affairs and in understanding those matters, knowledges, and forms of reasoning that could inform it (Eikeland, 2008; Elliott, 1987).

We believe that the social turn of action research maximized its heuristic and transformative scope but at the same time exposed it to new risks. These mainly had to do with potentially relativizing knowledge, either as a result of the atomization of the social milieu (by considering it as a diversity of disconnected social practices) or under the influence of postmodernism's severe questioning of knowledge (Lyotard, 1984; Rorty, 1991). The main philosophical tenets of the sociocultural turn could be characterized in the following way. First, as befits the only biological species whose environment is always and already social, action research shifted and became rooted to a social ontology. Praxis (which in Freire's understanding also involves ideas) is exclusively human, while action not necessarily so. Accordingly, historically determined social practices such as education, health, social welfare, community service, and so on, replaced abstract references to an environment that was acted upon. Likewise, action no longer issued from an isolated individual but became necessarily connected to collective, normative, often institutionalized bodies of practical knowledge. The agents of the actions became the "custodians of the practice for their times and generation," as Kemmis (2010, p. 420) described them, whose actions were necessarily "intentional" in the Weberian sense (Boog, 2003). Since practices were fully embedded in social life, action research also structured itself around "life experiences" (Dewey, 1934, pp. 2-3), vivencias (Fals-Borda, 1991, p. 11; Glassman \& Erdem, 2014), in which emotions and cognitions had their place.

In conclusion, through the sociocultural turn, the loyalty of action research shifted from simple actions to social practices that contained them, which became the key ontological sites where action research in each case filled its dimensions with meaning. Actions became relevant not only on account of their heuristic potential to validate or falsify hypotheses and produce knowledge about the environment-which was how action learning ( $\mathrm{O}^{\prime}$ Neil \& Marsick, 2007) and the learning cycle (Kolb, 1984) basically understood them. Beyond this, actions were significant in terms of their internal, axiological rationality, since they were the means through which different social practices realized aims and values that action research embraced as part of its subject matter.

The nature of the sociocultural approach to action research can best be summed up by comparing the definition by Coghlan and Shani (2005), presented earlier- "Action research is about undertaking action and studying action as it takes place" (p. 533)-with the basic rendition of action research by Carr and Kemmis (1986, p. 162), which has remained nearly intact for more than 30 years, since they first included it in their classical work, Becoming Critical. In the following version, McTaggart (1994) added a final point that amplified its scope: "Action research is a form of self-reflective enquiry undertaken by participants in social situations in order to improve the rationality, justice, coherence and satisfactoriness of (a) their own social practices, (b) their understanding of these practices, and (c) the institutions, programmes and ultimately the society in which these practices are carried out" (p. 317). This definition brings many planes of reality together-situations, institutions, society-that overlap around the axis provided by the social practices. Each additional level brings on board further degrees of complexity and (potential) conflict, which one must take care to understand and explore. And yet, as occurs whenever there is a looming threat of contradiction, one 
should proceed by establishing a clear hierarchy among the factors involved. The dominant aspect in the social ontology of action research is that nothing-not the epistemological, methodological, ethical, or political dimensions-should stand beyond or above the situated social practices, with their special aims, values, principles of procedure, signs, tools, knowledges, and discourses, including their own literacies-in short, their "common traditions of understanding" (Elliott, 2009) or internal cultures (Stenhouse, 1967), laden with their own theories and ethical or deontological standards.

In other words, action research must find a harmonious way to reconcile and articulate the epistemological and methodological standards of research with the practical dimensions stemming from its rootedness in specific social practices. The basic unit of this sociocultural ontology-the social practice and its internal culture-limits the scope and shapes the meaning of all the remaining levels of action research. At the research level, for example, this principle establishes a clear hierarchy that systematically privileges the practical principles to the epistemological and methodological ones, or better put, shapes the epistemological and methodological realms to better suit the practical demands. Thus understood, there is no conflict: research becomes the most adequate means for practitioners to channel, express, refine and reinvigorate their own vocation (Feldman, 2007b), or for professionals to pursue and maximize their professional development (Stenhouse, 1975; Tripp, 1987). In the words of Elliott (1991), "the fundamental aim of action research is to improve practice rather than to produce knowledge. The production and utilization of knowledge is subordinate to, and conditioned by, this fundamental aim" (p. 49).

Compared to positivistic forms of research, the specific quality of action research lies then in that inquiry is a way for the people engaged in different social practices to better realize the latter's aims. Rather than making a lasting contribution to universal knowledge, action research is interested in producing only "the knowledge that counts" (Stark, 2014, p. 96), "implementable" (Dick, 2004, p. 428), "catalytic" (Lather, 1986), "extrinsically relevant" (Hammersley, 2004, pp. 167-168), "valid and vital knowledge" (Brydon Miller et al., 2003, p. 11), instrumental for the purposes of the social practice concerned. Hence the appropriateness of the claim by Argyris (1997) that "action research, at its core, is normative and prescriptive" (p. 812) but also axiological-we should add-since it is constantly accompanied and enlightened, in each case, by values that define the quality standards specific to each internal culture. These values must also permeate the process of inquiry. Only collaterally may the insights deriving from the research separate themselves from those specific aims and contribute to Science with capital letters, to "objective, value-free, expert science" (Wicks, Reason, \& Bradbury, 2008, p. 19), we could say, and to the general expansion of human knowledge. Although viable, this development remains external to the original nature of action research.

As a result, action research has been described as practitioner research (Zeichner \& Noffke, 2001), a term that seems apt as long as one keeps a flexible definition of practice in mind, one which does not automatically equate it only with professions or practices that are institutionally inscribed. The following formulation by Kemmis, Heikkinen, Fransson, Aspfors, and Edward-Groves (2014) satisfies this demand: 
We define a practice as a form of socially established cooperative activity that involves characteristic forms of understanding (sayings), modes of action (doings), and ways in which people relate to one another and the world (relatings), that hang together in a distinctive project. The project of a practice is what people say when they sincerely answer the question "What are you doing?" while they are engaged in practice. (p. 155)

\section{Epistemology, Methodology, and Ethics of Action Research}

The hierarchy is set: the practical demands that issue from the social ontology of action research shape and take precedence to the epistemological and methodological ones, as habitually defined by positivist science (Feldman, 2007a; Lomax, 1995) or even pragmatism. Instead of considering research as the autonomous endeavor whereby detached observers discover and produce knowledge about the objectified word and then submit it into mathematical codification (Ayer, 1959), action research locates inquiry at the heart of every social practice, as a significant resource for its members to constantly improve their own actions and their internal rationalities. This implies a profound redefinition of research, of epistemology and methodology, a "paradigm shift," as Reason and Bradbury (2008) argue, "changing what we take as knowledge" (p. 698). The result is that epistemology and methodology are rendered unrecognizable to positivist science.

\section{Epistemology}

Let us start with the epistemological consequences. Most action researchers would agree that the knowledge they produce is perforce local, axiological, and context dependent. This does not mean that transfers between research contexts cannot take place, or that particular investigations cannot prove or disprove ingrained hypothesis and thus "contribute to the development and refinement of theoretical models," as Cummins and Early (2011, p. 19) argued regarding action research case studies in the field of education (the assumption being, of course, that "the practically relevant features of particular action contexts will tend to repeat themselves across contexts" (Elliott, 2009, p. 35)). The context-dependent nature of action research notwithstanding, not all action researchers would defend that all knowledge is local, axiological, and context dependent, as the postmodernist strands of action research seem to affirm (Kilgore, 2001). Although it has only minor practical effects, this debate draws a potential dividing line in the epistemology of action research. For it often occurs that, to justify themselves, action researchers present their own paradigm as the only coherent realization of a deep epistemological truth that would cover both the social and natural realms. The postmodern assumption that "objective knowledge is impossible, since the researcher is always part of the world under study" (Katsorou, 2017, p. 680) is inaccurate and simplistic considering that the four landmarks of modernist scientific thought-Darwin's, Marx's, Freud's, and Einstein's-proved that the observer's participation in the world was a phenomenon that led to epistemological distortions (Collier, 1994), yes, but also that science could penetrate, conceptualize, and methodologically discount these distortions to a large degree (Villacañas de Castro, 2016). So, the observer's participation in the subject matter does not imply that all knowledge must be necessarily relative, reversible, or subjective, as postmodernism seems to suggest. And the same occurs with the axiological, value-ridden nature of any piece of inquiry. "All research is embedded within a system of values and 
promotes some model of human interaction," Brydon Miller et al. (2003, p. 11) sustained. Yet this does not mean that systems of values necessarily affect the quality of the research itself. Not only is action research framed within a given set of values-those of specific social practices-but value redefinition and clarification are an essential part of its subject matter. However, not all forms of inquiry include values as part of their subject matter.

\section{Methodology}

Action research's redefinition of methodology is a complex issue prone to generate discontinuities and internal divisions. Variety notwithstanding, one principle is embraced by all: inquiry must be exercised by the practitioners, by the members of the social practices themselves. "Participants," reminds McIntyre (2008), must "engage in all aspects of the [action research] project" (p. 12). This imperative derives from everything that has been said so far, and it will be implicit in everything that is added from now on. As defended by Van Lier (1994), action research disqualifies from the onset any kind of Blitzskrieg approach whereby inquiry is done neither with practitioners nor in line with their interests and concerns but rather by researchers who, once they take the data, "disappear to make and publish their results" (p. 33). In this sense at least, Swantz (2008) associated action research with Johan Galtung's idea of a "non-violent social science" (p. 32) that would neither objectify the people taking part in a research (Jordan \& Kapoor, 2016) nor force and bend their behaviors and thoughts. Ultimately practitioner participants were also members of a given social practice by whose values the whole research must abide.

Additionally, although there exists a wide range of variability in the actual degree of practitioners' participation in an action research-especially when teams include external trained researchers who act as animators (Rahman, 2008, pp. 52-53) or facilitators (Avgitidou, 2009), as is the case in collaborative action research - the methodological viability of this paradigm ultimately depends upon this participative character. First and foremost, only inside practitioners can establish which the aims of each social practice are, and hence also of the action research projects going on inside them. If need be, these basic aims can be clarified, reworked, reformulated, and changed during the action research project, but they cannot be imposed from the outside. Second, sometimes the participatory nature is a precondition for the actual data-gathering phases to take place, to the extent that in many cases the essential processes and reality of the social practice can only be accessed by insiders, while the rest are institutionally barred: "Real classrooms have to be our laboratories," reminded Stenhouse (1979), "and they are in the command of teachers, not of researchers" (p. 133). Finally, from a transformative perspective, if changes triggered by these initiatives are to be sustainable in the long run (Salleh, 2006), practitioners must also remain the main agents of the learning process, or otherwise they will not grow to be autonomous and capable of prolonging the changes over time (Banegas \& Villacañas de Castro, 2019).

Still in relation to the methodology of action research, a major critical issue is the degree to which action researchers will (a) stay loyal to prevailing renditions of the scientific method as the point of reference for grounding their research designs, or whether, on the contrary, they will (b) take the internal traditions or cultures of their social practices as the starting point. This dichotomy reflects a tension, shaping action research from its historical conception as an approach to inquiry that, notwithstanding its participatory character, was created by 
university researchers (Fals-Borda, 2006; Greenwood \& Levin, 2005), however discontent they were with their institutions. This paradoxical origin explains why the presence and role of a trained expert or professional researcher remains unquestioned in action research projects (Greenwood, 2017), despite its ancillary and inessential character. This is specially the case with projects falling into option (a). The main problem with this position is that the more one essentializes the need for an external researcher, the more the chances that the following dynamics will eventually take over, not only in education but whatever is the social practice involved: "if the stance is taken that [. . .] research must be specialized and use formal protocols that go beyond ordinary teaching, most teachers will not do it, will not see themselves as researchers, and will experience a loss of self-respect" (Shosh, 2017, p. 16). Furthermore, if practitioners $d o$ go ahead and participate in these research projects, they might incur a form of epistemic drift (Bridges, 1998) by adopting methodological criteria they do not believe in and consider irrelevant for the improvement of the social practice.

Options (a) and (b) carry with them a whole set of parallel consequences. For example, while both try to account for the methodological variety and wealth of action research (Dick, 2015), they justify and understand this diversity differently. Those inclined to fall back, no matter how vaguely, to traditional notions of research and to expert researchers who would be responsible for unfolding them, will also be more prone to affirm that action research has a well-established, unified research methodology: the well-known spiraling structure of ongoing cycles first described by Lewin (1946) and later reelaborated by Kemmis and McTaggart (1988), McNiff (1988), Elliott (1991), and so on. By privileging this cyclical structure, by equating it with action research's methodology par excellence, methodological diversity is forcefully reined in and pushed to a lower plane, safely kept within the bounds of datagathering and analysis methods (Feldman, 2007a). Even then, these would remain mainly qualitative.

In contrast, option (b) calls for action researchers to bypass traditional conceptions of research, directly engage the internal traditions of each social practice, and find therein the necessary resources to gradually and organically build a practice-specific culture of inquiry. Practitioners can learn from academic forms of scientific research, but above all they must learn from (and transform) each other and themselves. According to Somekh (2008), "action research is always grounded in the values and culture of the participant researchers who engage in and, as a result, is a fluid methodology that adapts to fit different social contexts" (p. 6). Each social practice would be justified to develop its own research (sub)culture, the one best suited to sustain practitioners as they embark on a self-reflective inquiry to reshape their practices and realize their aims. As a result, there could be as many research methodologies as there are social practices.

This vision poses some difficult questions to the action research community-first and foremost, it problematizes the existence of an "action research community" itself (an idea that lies at the base of interdisciplinary action research platforms, associations, and journals). Precisely because option (b) sees practitioners-not university researchers-as the cornerstone of action research, it also considers that there can be no action research in general, disconnected from each social practice (actually, the existence of a professional researcher would be an oxymoron); in the same way as there would not exist an underlying action research community capable of transcending, through a common methodology, each social practice. Once again, the boundaries of each social practice and internal culture would 
be absolute boundaries that would coincide with the frontiers of action research in each case. It is not surprising that, thus conceived, action research should dispense with the notion of "methodology" altogether as a superfluous remainder of positivism (Elliott, 2009), of the oppressive institutional hierarchy that divides theorists from practitioners, and finally as an obstacle for action research to bring its coherent project to full turn (Adelman, 1989; Carr, 2006; Cook, 2009). Paradoxically, it might be the case that common belief in these radical ideas acts as a unifying force among action researchers.

Option (b) finally points at the need for action research to become multiliterate and multimodal in its methods for it to welcome the wide range of internal cultures that lie within the multiple spheres of society. Schools and strands of action research in developing countries have shown a stronger awareness of this methodological necessity than Western ones, possibly on account of the huge spectrum of languages, cultures, and literacies (and illiteracies) that they were exposed to from the start. At least since Freire (1973) first used visual slides in his own cultural cycles to spark research, discussion, literacy, and action with peasants in Northern Brazil, action research has known of the need for practitioners to creatively draw on myriad genres and means of expression-often retrieved from folk, indigenous, or popular culture (Fals-Borda, 1991)—both to channel the inquiry and share the research outcomes. Slowly, this realization has slipped into Western action research projects, especially those conducted with underprivileged collectives (Garcia, Mirra, Morrell, Martinez, \& Scorza, 2015; McIntyre, 2008). Key advances in the field of literacy education (Street, 2012) have also contributed to action researchers welcoming a wide range of registers, literacies (academic as much as informal), and modalities (printed, visual, audiovisual, artifactual, etc.) to realize their project aims through formats as diverse as photovoice (Pauwels, 2015; Wang \& Burris, 1997), poetry (Barrett, 2011), drama (Cahill, 2006), visual art (Li, Kenzy, Underwood, \& Severson, 2015), (digital) storytelling (Caxaj, 2015), and so on. The methods of action research need not be qualitative or remain trapped in the dichotomy that opposes them to quantitative perspectives; for it is easy to imagine practitioners who, on account of their professional background, might be familiar and comfortable with mathematical literacies and hence decide to channel their action research through quantitative approaches. It should not come as a surprise that case study grew as the privileged and most coherent method to channel these epistemological and methodological perspectives (see, for instance, McDonald \& Walker, 1975). With case study, the emphasis lay on describing and understanding the developments experienced from within a given parcel of a social practice rather than on searching for patterns that could transfer to other theoretical and practical domains.

Methodological and epistemological diversity notwithstanding, demands and rigor and validity persist. In this regard, and apart from the actionability principle (Argyris, 2003), quality criteria in action research have often been understood as being of a reflective kind, as exemplified by recoverability principle- "the process by which the research was undertaken must be recoverable by an external audience in relation to the methodology" (Burns, 2005, p. 67)-or by the need for practitioners to fully justify their methodological choices. An example would be to make sure that reports "include clear and detailed descriptions of how and why data were collected [. . . and] make explicit what counts as data in their work" (Feldman, 2007a, p. 30). However, one must underscore that quality criteria shall remain for the members in each social practice to decide: "Through their own social processes people establish their own collectives and their own verification systems," claim Lykes and Mallona (2008), "thereby establishing themselves as fully scientific" (p. 110). 
Despite being more cohesive with the ontological underpinnings of action research, option (b) -that practitioners build on their internal cultures to create their (sub)cultures of inquiryhas one fundamental disadvantage: it may lead to a new form of epistemological relativity based on the ontological autonomy of each social practice. That is, the risk may befall that the latter behave as islands, monads, self-contained entities, each with their own aims, internal cultures, research (subcultures), and particular conceptions of knowledge, which would not necessarily be shared by others or generally agreed upon. Transferability of action research insights from one social practice to another would be frustrated by this absence of a common view. While the social ontology of action research provides it with its specific epistemological potential, on the other hand it can do little to avoid the risk of the whole paradigm gliding down the slope of discourse incommensurability (Biagioli, 1990) and untranslatability (Herzfeld, 2003), where different social practices find it impossible to make their research bases and contributions understandable and profitable to each other, and to society as a whole. The expectation that the quality criteria presented above might act as safe guarantee and homogenizing force might be without base, bearing in mind that Argyris's actionability principle continues to be internal to each social practice. Recoverability and methodological justification, on the other hand, might afford some desired common ground. The irreducible autonomy of each social practice can also stifle the democratic and emancipatory potential of action research, not only considered in a Marxist sense-involving entire social classes-but especially if we believe the role of action research to be the "constitution of public spheres for communicative action," as Kemmis and McTaggart (2005, p. 559) do.

\section{Ethics}

When approached from the ethical or deontological dimension, option (b) has fundamental advantages as well. Most important among them is the possibility of avoiding collusion between the ethical principles of positivist research methodology and the specific deontological norms of each social practice. This is an essential point, since action researchers have encountered potential contradictions that flow both ways (Banegas \& Villacañas de Castro, 2015; Brydon-Miller, 2008). In one direction, the participatory nature of action research easily oversteps the orthodox ethical standards of mainstream quantitative and qualitative research, for example, in relation to privacy issues or the distance that is normally kept between the researcher and the researched (Zeni, 1998). In the other direction, standard research ethics as those exemplified in the Belmont Report (Department of Health, Education, and Welfare, 2000) can impinge upon some of the deontological safeguards established by a given social practice to keep at bay actions that could harm, contradict, or deform its values and aims. This is a reasonable risk, especially as neoliberalism colonizes the majority of social spheres with epistemological and methodological dogmas of what "good" and "reliable" research is (de Sousa Santos, 2015). Far from that, by using their internal cultures as breeding grounds to grow their own specific research subcultures, action researchers make sure that the deontological principles that rule their social practices become translated into their research ethics. In no way should the process of inquiry of action research disrupt the fragile ecologies on which the realization of the specific aims and values ultimately depends. 


\section{Educational Action Research}

When applied to the social sphere of education, the above principles translate themselves into the following simple, golden rule: "as teacher researchers, our primary responsibility is to our students" (Zeni, 1998, p. 16). Stenhouse (1979) reformulated this maxim by arguing that "teachers cannot learn by inquiry without undertaking that the pupils learn too, [just as the] the physician cannot experiment without attempting to heal" (p. 133). These two formulations imply that, unlike behaviorist research paradigms in education, which often force teachers to either research or educate (but never do both things at the same time), educators working through action research must make sure that the experimental situations they design are rich, are educational, and give students a real opportunity to learn-that is, that they are indistinguishable from the curriculum itself. Hence, Stenhouse (1975) and Elliott (1991), in rereading curriculum theory of Schwab (1969) in terms of educational action research, present its hypotheses as curricular proposals, testable in real classroom settings. These proposals had to include not only a series of aims but also teaching strategies and a set of principles of procedure for other teachers to follow-the educational equivalent to Argyris's actionable hypotheses. The curriculum, the teaching unit par excellence, thus became the key methodological unit of educational research (Bascia, Carr-Harris, Fine-Meyer, \& Zurzolo, 2014).

According to Stenhouse (1988), behind this program was the felt unease of educators and teacher educators toward research that, despite being rooted in their social practice, had a psychological or sociological orientation instead of an educational one: its research methods and designs isolated psychological and sociological variables rather than respecting the natural classroom environment where education, as a social practice, took place (McComas et al., 2018). Not only was this impractical in terms of improving actual teaching, but there was also the suspicion that by breaking down education into isolated variables, these research designs did not fully grasp the phenomena they claimed to study. For example, by disconnecting student cognition from the whole range of factors that educators actually negotiate in their classrooms through their pedagogies and curricula-student motivation, identity investment, culture, cultural capital, home and school literacies, and so on-by treating learners only as cognitive apparatus rather than as fully sociocultural beings and, in turn, considering that these sociocultural dimensions (all of which intervened in natural classroom contexts) were independent from the cognitive one, these studies would not even be providing an adequate experimental context for students to actualize their true talents and intelligence. Nor were they, accordingly, able to measure or understand them. If this was the case, research and policy might then be grounding their conclusions and decisions on partial, deformed data. Hence the need to conceive a research paradigm for "an educational science in which each classroom is a laboratory, each teacher a member of a scientific community" (Stenhouse, 1975, p. 142).

This paradigm was educational action research. If, by definition, action research was context dependent, situation dependent, and responsive, this meant that inquiry and education not only had to develop in the same educational scenario and dynamics but had to do so in a holistic manner. There is ample evidence of practitioners being able to strike this balance (e.g., Mackay, Birello, \& Xerri, 2018) by turning their classrooms into convergence spaces where teaching, learning, and researching meet and operate in tandem to empower those 
actors who bring forward their planned educational aims. This is a feasible goal, if the curriculum-teaching strategies, learning tasks, materials, and so on-becomes a research tool and teachers and learners enact both teaching and learning together with researching. Academic and research freedom for all educators to innovate and experiment with the curriculum (McKernan, 2008), irrespective of their teaching level, would be a basic precondition for this program. Formal education often operates within the constraints of a received/imposed curriculum which acts as a sociopolitical organizer; however, when put to play in a specific setting, this expected curriculum often enters into an inescapable scenario in which tensions emerge between the expected curriculum and the observed or enacted curriculum. It is precisely the enacted curriculum which can be transformed by the outcomes of educational action research, and there may be instantiations where the sum total of transformations in the enacted curriculum may inform and transform completely the received curriculum.

When educational action research is operationalized from an ecological perspective, research does not occur before or after teaching but while teaching and learning are being enacted. Teachers benefit as they deepen their understanding of their own teaching practices, thus assuming clear agency over their professional development, which now revolves around curriculum experimentation and development. This process is bound to reframe their professional identities as well, as they become teacher-researchers (Banegas \& Villacañas de Castro, 2019; Edwards \& Burns, 2016) capable of examining their practices and theorizing them in ways that promote their autonomy, vocation, and a more democratic and fairer access to knowledge. Concerning systematization and data collection instruments, for example, teachers can use recording instruments, such as journals or observation checklists; analyze their lesson plans, teaching artifacts (e.g., assigned texts, materials, assignments), and interviews; or count on a critical friend/peer teacher to engage in peer observation. All these tools are naturally used by teachers in their classrooms and belong in their professional cultures. In addition to them, once ethical considerations have been fully addressed (Banegas \& Consoli, 2020; Mitra \& McCormick, 2017), teachers may even take photographs or video/ audiorecord their lessons in order to engage in conversational analysis to detect interactional patterns that promote or compromise learning. Nevertheless, educational action research should not only drive teachers to scrutinize their practices but also to encourage them to review the extant literature on the topics they investigate. Should such teachers move further and socialize their findings through staff meetings, workshops, conferences, or articles for publication, their experiences and findings would be validated and peer reviewed by colleagues immersed in communities of practice which seek to value indigenous research.

By the same token, learners can benefit from action research ingrained in educational ecology. Learning artifacts and outcomes contain valuable information which could hint at what has been taught and learned and how. Also, self-reporting is triangulated or crystallized (Ellingson, 2008) through data coming from the actual learning and teaching processes themselves. Not only can such a wealth of information be gathered by teachers to compare perceptions and outcomes, it can also be reflected upon by learners themselves. Learners can be guided to think about why they completed a task in a specific manner or why some of their answers are correct or incorrect depending on the context in which learning develops. In the same manner as teachers, learners can also keep a journal in which they systematize their lived experiences. In this matrix, learners may become educational co-researchers (Pinter \& Mathew, 2016), as they are guided into analyzing their own perceptions and evidences of 
learning, thus engaging in meta-learning. This new positionality further challenges those research frameworks criticized above, usually underpinned by psychometric traditions or qualitative methods, that stress the distance between university-based academics and practitioners, and in which learners are mere instruments, passive informants of discrete behaviors who do not benefit from either learning or researching, nor do their contributions feed back into the environment.

In conclusion, from an ecological perspective, teachers and learners benefit from educational action research; if they benefit, the teaching and learning processes are necessarily transformed as they are enacted and delineated by those who gravitate at the center of education-learners and teachers-around the curriculum.

\section{Social Practice, Democracy, and Action Research}

To analyze the political dimension of action research, let us reproduce McTaggart's answer to the question "What really is the purpose of social research?" in the collective piece brought together by Brydon-Miller et al. (2003). "The answer to this question to me now is quite straightforward: the improvement of social practice" (p. 13). The response is coherent both with the ontological dimension of action research and the epistemological and methodological consequences we have drawn from the previous sections. Now, from a political perspective, McTaggart's answer calls forth a reevaluation of statements that for decades identified the political dimension of action research with aims coming from other theories, projects, disciplines, and discourses, be it the realization of "human flourishing" (Reason \& Bradbury, 2008, p. 1), "the good of humankind" (Kemmis, 2010, p. 424), attaining socialism (Rahman, 2008), or resisting global imperialism and plotting alternative globalizations (Rowell \& Hong, 2017). Equating action research with any of these terms does not entail an illogical move if the equation can be explained in terms of the key ontological unit-social practice-and its direct political translation: its improvement.

At this point a critical reading of Marxism seems necessary. Notwithstanding the latter's diverse understanding of society and social practices, by forcing this contrast we expect that the political contours and riddles of action research-complex, paradoxical, and sophisticated as they are-can be identified in broad daylight. Conversely, the influence of Marxism in action research was never univocal. A strong inspiration behind Latin American strands of participatory action research (Flores-Kastanis, Montoya-Vargas, \& Huárez, 2009; Glassman \& Erdem, 2014) that originated in the 1970s around adult literacy campaigns of Freire (1973), movements of land reform, and projects by Fals-Borda (1985) in rural Colombia (Rappaport, 2017); part, also, of the PAR (Participatory Action Research) framework dominant in Asia (Tandon, 2017), Africa (Swantz, 2008), and other parts of the developing world, Marxism gave action researchers the chance to picture themselves within an all-encompassing philosophical, ideological, and political project. Fals-Borda (1979), for example, embraced action research as a viable strategy to produce a real "science of the proletariat" (p. 48) and Rahman (1985) argued that it could contribute to the working classes taking ownership of the means of knowledge production, an essential step for ultimately controlling the material ones. 
This does not mean that Fals-Borda and Rahman, or Freire before them (Allman, 1994), were unaware of the tensions involved in trying to reconcile Marxism with these forms of participatory research. This conflict can ultimately be expressed in terms of Marxism being ontologically, epistemologically, and methodologically grounded on the mode of production, not on individual social practices. Like action research, Marxism recognized the existence of different social practices; unlike it-in this, action research is closer to the sociology of Habermas (2003) - Marxism did not concede autonomy to each of them. Its understanding of the mode of production included a clear hierarchy among the different social practices that also applied to the knowledges each was able to generate. Based on theories of Marx (1977, ch. 12, 1991, ch. 19; Marx \& Engels, 1978), theories of ideology, fetishism, and phenomenal forms (Villacañas de Castro, 2016), a fundamental epistemological tenet of Marxism was that social practices never were transparent to themselves, that is, that in their day-to-day activities practitioners only accessed partial, deformed, ideological, commonsensical representations of their own activities and of the spheres (and the society) in which they labored and were involved. As a consequence, the true meaning of each social practice could only be properly understood through a scientific articulation of the entire mode of production, whose structuring principle, in turn, lay always in the economic sphere, which determined "in the last instance" the rest of social practices (Althusser, 1962).

From an action research perspective, the problem with this argument was that it placed practitioners at a very difficult, nearly untenable, position. Instead of considering them the faithful "custodians of their practice" that Kemmis (2010, p. 420) claimed they were, Marxism assumed that the meaning of each social practice lay outside itself, opaque to the very people taking part in them. For Marxism, the meanings that each social practice assigned to itself were neither essential entities nor autonomous units of analysis; hence, they were not to be directly trusted, derivative as they were of economic production. At best, Marxism enacted a symptomatic reading (Althusser, 2016) of practitioners' accounts, considering them expressions of a truth the speakers had no cognizance of. At its worst, Marxism did not even regard these standpoints as approximations to truth: Swantz (2008), for one, was concerned that the religious interpretations of the world voiced by participants in action research projects were frequently disdained and ignored by Marxist researchers as superstitious and uninformative. Freire, Fals-Borda, and Rahman denounced this attitude as dogmatic, ultimately antipedagogical (Flores-Kastaris, Montoya-Vargas, \& Suárez, 2009), and contradictory to the basic tenets of action research. By proceeding this way, researchers were clearly running the risk of, as Giroux (2006) says, "being theoretically or ideologically correct and pedagogically wrong" (p. 63). In practice, Marxism's strong version of scientific truth (in this it remained closer to positivism) frequently became translated into researchers feeling tempted to impose preestablished knowledge objectives, even to treat dialectical materialism as a basic methodology, or to prioritize any of these two to the collective and organic analysis and refinement of the practitioners' internal cultures through methods and discourses they were familiar with, as action research recommends. Rowell, Bruce, Shosh, and Riel (2017), for example, recounted how this "activist stance [. . .] has rigidified action research and participatory methodologies into political programs [. . .] more oriented toward pre-set political agendas than toward an ethical practice" (p. 7).

Despite this tension, it is important to underline that nothing prevents action researchers from developing a wider plane of reflection to, for example, address the internal dynamics of capitalist society. Action research projects start from a given situation, from existing social 
practices, yet they may well end up addressing "the institutions, programmes and ultimately the society in which these practices are carried out" in a critical manner, as McTaggart (1994, p. 317) suggested. The function and role of the different social practices (and of the practitioners inside them) in instantiating the status quo can be explored. The same holds true for its political dimension, which one may link to the class struggle, revolution, workers' democracy, or any other concept originating from the Marxist tradition. Action research is eclectic: it continues to find inspiration in many different traditions, and there is nothing internally problematic in this. Yet in all these cases-as in those instances when action research explicitly embraces the aims of feminism (Maguire, 2006; Reid \& Frisby, 2008), antiracism (Donald et al., 1995; Torre, 2009), social justice (Brydon-Miller \& Damons, 2019; Romero et al., 2008), ecological sustainability (Kemmis \& Mutton, 2012; Marshall, Coleman, \& Reason, 2017), and many more transversal issues currently being explored by action research in many social practices, it is important to realize that when action research brings on board concepts from wider fields and discourses, it should not sidestep the aims and values of the concrete social practices. Internal cultures can and must be enriched and expanded, never betrayed or ignored. This means that, just as action research was only collaterally interested in producing knowledge (Elliott, 1991), the struggles for feminism, against racism, and in favor of social justice-valuable and necessary as they all are, also for education-should be linked to the specific aims of the social practices involved and contribute to their improvement. "Political agency," as Kemmis and McTaggart (2005) explained, should develop as "a corollary of heightened understanding and motivation" (p. 571) and not the other way around.

Despite Marxism's influence in action research, when action researchers summon democracy or emancipation, it is mostly in opposition to another all-encompassing, dogmatic project: not Marxism but neoliberalism and its urge to flatten out the global and social landscape through a single economic ratio (Harvey, 2005). Neoliberalism's attempt to break down the indivisible quality of each social practice-to bend their internal cultures and make them conform, through increased accountability and bureaucratization (Power, 1997), to quantitative criteria of economic efficiency or value-for-money rationality (Adi \& Dutil, 2018; Stone, 2002)-is premised on the assumption that the meanings of the different social spheres is not for autonomous professionals to secure and determine. Unlike Marxism, under neoliberalism this meaning is just for the market to decide. So either through direct privatization of public services (Morales, Gendron, \& Guénin-Paracini, 2014) or through new public policy management (Siltala, 2013), neoliberalism attempts to substitute supply and demand for all other social rationalities. This tendency has clear epistemological, methodological, and political consequences (Dardot \& Laval, 2010). Contrary to neoliberal methodology, the strategy of action research is to strengthen practitioners' autonomy precisely so that, through their efforts, social practices can resist devaluation (Broudy, 1981) and economic colonization from outside actors. The expectation is that by holding on to their specific ratios not only will practitioners access the internal goods (MacIntyre, 2011) of their professions but also ensure that human and economic resources are allocated, distributed, and deployed according to a wider diversity of social aims, needs, and perspectives (educational, cultural, welfare related, etc.) than those mobilized and spent in the interest of capital accumulation. If only as a bulwark against market totalitarianism, action research remains a valuable tool for the benefit of democracy and pluralism. 
At the more general plane, apart from the specific gains accrued at the level of the social practices, action research projects should also be understood as the first step in an "ongoing process of citizens working toward cooperative, shared governance of social institutions, including those of the market," which was how Box, Marshall, Reed, and Reed (2001) described Dewey's project of a democratic society. From this perspective, action research, although local and practice-specific, would also belong in a bigger, emancipatory picture in which practitioners would gradually take control, as citizens and human beings, of all the dimensions in their life (material and immaterial alike), precisely by insisting on action research's expanding democratic spiral, and letting themselves be carried forward by it (Villacañas de Castro, 2019).

\section{Conclusion: Action Research and Pedagogy}

This article set out to organize a philosophical argument capable of illustrating how action research became rooted on a pluralistic ontology of social practices that necessarily redefined its epistemological, methodological, ethical, and political dimensions, and ended up giving action research its characteristic cohesiveness-one which, however, is not without tensions. At the same time as it fulfilled this aim, the article has also proved educational ideas to be firmly ingrained in action research theory and practice, hence the need to bring awareness to the pedagogical dimension in this final section. Indeed, as could be expected from a paradigm that includes Freire and Dewey among its original and strongest inspirators, many are the times in which the pedagogical dimension of action research is foregrounded in the literature (Wicks, Reason, \& Bradbury, 2008). Somekh (2010), for example, argued that "action research is always a learning process, and in trying to bring about improvements in human interactions -whether in health or social work setting, or as a participant in a community group-the action researcher is always engaged in an educative process" (p. 104); Kemmis and McTaggart (2005) defined action research as "a social-and educational-process" (p. 563); Santoro Franco (2005), in turn, considered action research to be "eminently pedagogical research" (p. 488), while Boog (2003) directly affirmed that "action research is social research connected to an educational intervention" (p. 436). All these ideas point to the "powerful notion"-as Coghlan (in Brydon Miller et al., 2003, p. 13) described it-that, if improvement of social practice is to be real, deep, and long lasting, then it must not be based on external impositions but on the practitioners' willful transformation through a process that can only be defined as educational. For action research, education-like inquiry-is a constant in life, not a phenomenon restrained to a specific social practice. Accordingly, the defining feature of action research is not that it dissolves the traditional dichotomies of the epistemological or political realms - truth versus falsity and science versus common sense, for example, or left versus right, criticality versus status quo-but rather how action research subordinates all of them to the pedagogical dimension, that is, to the creation and unfolding of an "opportunity structure" (Hope, Skoog, \& Jagers, 2015) that promotes practitioners' learning. It is thanks to this specific pedagogical rationality that action research succeeds in channeling its critical tension in ways that are respectful but also noncomplacent with practitioners, constructive and conducive to their growth.

One of the consequences of privileging this pedagogical dimension is the need to find a better concept to justify action research than the one often found in the model of communicative action by Habermas (1984) (Carr \& Kemmis, 1986; Kemmis, 2008). As a matter of fact, 
different from both the instrumental and communicative rationalities through which the German sociologist and philosopher understood the two basic forms of social action, pedagogical rationality wishes neither to use practitioners to alter a given social practice in ways that the latter do not trust or are not interested in-in the fashion of a neoliberal audit culture that exemplifies instrumental rationality-nor to convince or persuade practitioners of how they should act and think, by coming up with the best founded and most logical argument, as communicative actions have been described. Pedagogical rationality simply aims to help people learn, and this involves something different from the instrumental or communicative options. Every single aspect of action research, linked either to the epistemological, methodological, or political dimensions, must be oriented to facilitate practitioners' growth, understood according to Dewey (1916): "Since growth is the characteristic of life, education is all one with growing; it has no end beyond itself" (p. 62). Not that practitioners learn something in particular, or that they learn for some specific purpose; rather, the main aim of action research is that practitioners learn and grow as much as they can, as much as their background cultures, knowledges, identities, languages, and literacies allow them to.

Youth Participatory Action Research (YPAR; Cammarota \& Romero, 2010) is the direct and specific translation of all these pedagogical ideas by practitioners working in the sphere of education. To be exact, YPAR is a teaching strategy that is increasingly being used in formal and informal educational contexts alike, at primary (Langhout \& Thomas, 2010), secondary (Caraballo, Lozenski, Lyiscott, \& Morrell, 2017), and university levels of education (Gullion \& Ellis, 2014). If, according to Wamba (2011), "both critical pedagogy and action research grew out of a critique of traditional empirical research and traditional pedagogy" (p. 173), then YPAR emerges precisely where pedagogical research (Santoro Franco, 2005) meets the research-as-pedagogy orientation that characterizes project-based learning (LaCueva, 2000). In consonance with the context-embedded nature of action research and its form of inquiry, YPAR projects do not investigate curricular contents and topics that are disconnected from the learners' surroundings but issues that directly affect their lives, issues that are shaping their families, neighborhoods, and communities. Methodologically speaking, they do so by explicitly managing and reflecting on the tension between their own local cultures, literacies, modalities, languages, and means of expression (Morrell, 2006), and the need to enrich and expand them toward more sophisticated and powerful research and citizenship skills. Inspired by the principles of project-based learning, YPAR projects give students the chance not only to discuss ideas and produce knowledge about reality but to fully engage in the material transformation of their surrounding world.

Taken as an educational concretion, YPAR in no way downplays the belief of action research in the pervasiveness of education, and therefore in pedagogy being a key component in any kind of social interaction. This pedagogical rationality of action research is not devoid of tensions which traverse the paradigm through and through, signaling its structural strengths and limitations. For example, when Hammersley (2004) argues that action research "maximizes the chance that relevant and usable information will be produced" but also adds that "this is achieved at the risk of overlooking the falsity of key assumptions built into the activity, and/or of failing to provide knowledge of underlying generative processes or about wider social forces" (p. 174), he is not actually criticizing action research but describing its unavoidable risks. The same holds true of the view of action research as not dependent on some "external source for theory generation" (Elliott, 1991, p. 116). The experience of action researchers has 
shown that action research is more a pedagogical endeavor than an epistemological one; it is pedagogical research directed at practitioner growth rather than at understanding reality at all costs. While it is true that the former cannot take place without at least some degree of the latter, the silent entente orchestrated by neoliberalism and positivist social sciences shows that epistemological exhaustivity can take place without parallel practitioner growth. In contrast, on account of its robust pedagogical foundations, we believe YPAR sets the standard for the utopian democracy that Dewey (1916) once envisioned; it realizes the kind of collective endeavors that, independently of the social practices in which they emerge and develop, should increasingly permeate and characterize democracies that deserve to be called so.

\section{Further Reading}

DePalma, R. (Ed.). (2019). La educación para el desarrollo y la ciudadanía global: Una experiencia de investigación-acción participativa. Barcelona, Spain: Editorial Graó.

Framed in critical and participatory action research, this volume offers rich accounts of PAR projects carried out in Galicia, Spain, with the aim of transforming learners' lives through global citizenship initiatives that connect invisibilized settings.

Mertler, C. A. (2018). Action research communities: Professional learning, empowerment, and improvement through collaborative action research. New York, NY: Routledge.

Driven by practical imperatives, the volume offers succinct, simple, and reader-friendly suggestions on how to establish professional learning communities led by teachers through collaborative action research.

Peim, N. (2018). Thinking in education research: Applying philosophy and theory. London, UK: Bloomsbury.

Although it does not strictly articulate action research as a central paradigm inquiry, it does encourage teacherresearchers to examine their own assumptions, engaging readers in key concepts akin to ontology, epistemology, and methodology.

Uribe Castro, H., Ayala Osorio, G., Hurtado Vera, G., \& Holguín, C. (2015). Una experiencia de investigación acción educativa: Reflexiones desde el aula. Bogotá, Colombia: Universidad Autónoma de Occidente.

Set in Colombia, the book sits at the intersection of action research, philosophy, and sociology, and it describes action research projects carried out with young learners in state schools.

Wright, D. E. (2015). Active learning. Social justice education and participatory action research. Abingdon, UK: Routledge.

The title discusses the findings from a U.S. project in which teenagers were involved in educational action research projects. The author conceptualizes participatory action research as a pedagogy for empowerment and social justice in which younger generations can play a pivotal role.

\section{References}

Adelman, C. (1989). The practical ethic takes priority over methodology. In W. Carr (Ed.), Quality in teaching: Arguments for a reflective profession (pp. 173-182). London, UK: Routledge. 
Adelman, C. (1993). Kurt Lewin and the origins of action research. Educational Action Research, $1(1), 7-24$.

Adi, S., \& Dutil, P. (2018). Searching for strategy: Value for money (VFM) audit choice in the new public management era. Canadian Public Administration, 61(1), 91-108.

Allman, P. (1994). Paulo Freire's contributions to radical adult education. Studies in the Education of Adults, 26(2), 144-161.

Althusser, L. (1962). Contradiction and overdetermination <https://www.marxists.org/reference/ archive/althusser/1962/overdetermination.htm>. Marxist Internet Archive.

Althusser, L. (2016). Reading capital. London, UK: Verso.

Argyris, C. (1997). Kurt Lewin Award Lecture, 1997. Field theory as a basis for scholarly consulting. Journal of Social Issues, 53(4), 811-827.

Argyris, C. (2003). A life full of learning. Organization Studies, 24(7), 1178-1192.

Argyris, C., Putnam, R., \& McLain Smith, D. (1985). Action science. San Francisco, CA: JosseyBass.

Avgitidou, S. (2009). Participation, roles and processes in a collaborative action research project: A reflexive account of the facilitator. Educational Action Research, 17(4), 585-600.

Ayer, A. J. (1959). (Ed.). Logical positivism. New York, NY: The Free Press.

Banegas, D. L., \& Consoli, S. (2020). Action research in language education. In J. McKinley \& H. Rose (Eds.), The Routledge handbook of research methods in applied linguistics (pp. 176-187). Abingdon, UK: Routledge.

Banegas, D. L., \& Villacañas de Castro, L. S. (2015). A look at ethical issues in action research in education. Argentinian Journal of Applied Linguistics, 3(1), 58-67.

Banegas, D. L., \& Villacañas de Castro, L. S. (2019). Action research. In S. Walsh \& S. Mann (Eds.), The Routledge handbook of English language teacher education (pp. 570-582). Abingdon, UK: Routledge.

Barrett, T. (2011). Breakthroughs in action research through poetry. Educational Action Research, 19(1), 5-21.

Bascia, N., Carr-Harris, S., Fine-Meyer, R., \& Zurzolo, C. (2014). Teachers, curriculum innovation, and policy formation. Curriculum Inquiry, 44(2), 228-248.

Biagioli, M. (1990). The anthropology of incommensurability. Studies in History and Philosophy of Science Part A, 21(2), 183-209.

Boog, B. W. M. (1989). Het aktionalisticsch paradigma van Alain Touraine cs. Hoogezand, The Netherlands: Stubeg.

Boog, B. W. M. (2003). The emancipatory character of action research, its history and the present state of the art. Journal of Community \& Applied Social Psychology, 13(6), 426-438.

Page 21 of 30

PRINTED FROM the OXFORD RESEARCH ENCYCLOPEDIA, EDUCATION (oxfordre.com/education). (c) Oxford University Press USA, Legal Notice 2020. All Rights Reserved. Personal use only; commercial use is strictly prohibited (for details see and ). Privacy Policy <https://global.oup.com/privacy> 
Box, R. C., Marshall, G. S., Reed, B. J., \& Reed, C. M. (2001). New public management and substantive democracy. Public Administration Review, 61(5), 608-619.

Bridges, D. (1998). Research for sale: Moral market or moral maze? British Educational Research Journal, 24(5), 593-607.

Broudy, H. S. (1981). Truth and credibility, the citizen's dilemma. New York, NY: Longman.

Brydon-Miller, M. (2008). Ethics and action research: Deepening our commitment to principles of social justice and redefining systems of democratic practice. In P. Reason \& H. Bradbury (Eds.), The SAGE handbook of action research: Participative inquiry and practice (2nd ed., pp. 199-210). Thousand Oaks, CA: SAGE.

Brydon-Miller, M., \& Damons, B. (2019). Action research for social justice advocacy. In C. A. Mertler (Ed.), The Wiley handbook of action research in education (pp. 371-392). London, UK: John Wiley \& Sons.

Brydon-Miller, M., Greenwood, D., \& Maguire, P. (2003). Why action research? Action Research, 1(1), 9-28.

Burns, A. (2005). Action research. In E. Hinkel (Ed.), Handbook of research in second language teaching and learning (pp. 241-256). Mahwah, NJ: Erlbaum.

Cahill, H. (2006). Research acts: Using the drama workshop as a site for conducting participatory action research. Drama Australia Journal (NJ), 30(2), 61-72.

Cammarota, J., \& Romero, A. (2010). Participatory action research for high school students: Transforming policy, practice, and the personal with social justice education. Educational Policy, 25(3), 488-506.

Caraballo, L., Lozenski, B. D., Lyiscott, J. J., \& Morrell, E. (2017). YPAR and critical epistemologies: Rethinking education research. Review of Research in Education, 41(1), 311336.

Carr, W. (2006). Philosophy, methodology and action research. Journal of Philosophy of Education, 40(4), 421-435.

Carr, W., \& Kemmis, S. (1986). Becoming critical: Education, knowledge and action research. London, UK: Falmer Press.

Carson, T. (2009). Teaching and cultural difference: Exploring the potential for a psychoanalytically informed action research. In S. Noffke \& B. Somekh (Eds.), The SAGE handbook of educational action research (pp. 347-357). Thousand Oaks, CA: SAGE.

Caxaj, C. S. (2015). Indigenous storytelling and participatory action research: Allies toward decolonization? Reflections from the peoples' international health tribunal. Global Qualitative Nursing Research, 2, 1-12.

Coghlan, D., \& Shani, A. B. (2005). Roles, politics, and ethics in action research design. Systemic Practice and Action Research, 18(6), 533-546.

Collier, A. (1994). Critical realism: An introduction to Roy Bhaskar's philosophy. London, UK: Verso. 
Cook, T. (2009). The purpose of mess in action research: Building rigour though a messy turn. Educational Action Research, 17(2), 277-291.

Côte-Thibaut, D. (1996). Historique de la recherché-action. In L. Lavoie, D. Marquis, \& P. Laurin, La recherché-action: Theorie et practique: Manuel d'autoformation (pp. 113-127). Quebec, Canada: Presses de l’Université du Québec.

Cummins, J., \& Early, M. (2011). Introduction. In J. Cummins \& M. Early (Eds.), Identity texts: The collaborative creation of power in multilingual schools (pp. 1-19). London, UK: Trentham Books.

Dardot, P., \& Laval, C. (2010). The new way of the world: On neoliberal society (G. Elliott, Trans.). London, UK: Verso.

Department of Health, Education, and Welfare. (2000). Belmont Report: Ethical principles and guidelines for the protection of human subjects of research. In B. D. Sales \& S. Folkman (Eds.), Ethics in research with human participants (pp. 195-205). Washington, DC: American Psychological Association.

de Sousa Santos, B. (2015). Epistemologies of the South: Justice against epistemicide. New York, NY: Routledge.

Dewey, J. (1916). Democracy and education. An introduction to the philosophy of education. New York, NY: Macmillan.

Dewey, J. (1934). Art as experience. New York, NY: Penguin Books.

Dewey, J. (1938). Experience and education. New York, NY: Kappa Delta Pi.

Dick, B. (2004). Action research literature: Themes and trends. Action Research, 2(4), 425-444.

Dick, B. (2015). Reflections on the Sage Encyclopedia of Action Research and what it says about action research and its methodologies. Action Research, 13(4), 431-444.

Donald, P., Gosling, S., Hamilton, J., Hawkes, N., McKenzie, D., \& Stronach, I. (1995). “No problem here": Action research against racism in a mainly white area. British Educational Research Journal, 21(3), 263-275.

Edwards, E., \& Burns, A. (2016). Language teacher-researcher identity negotiation: An ecological perspective. TESOL Quarterly, 50(3), 735-745.

Eikeland, O. (2008). The ways of Aristotle: Aristotelian phronesis, Aristotelian philosophy of dialogue, and action research. Berlin, Germany: Peter Lang.

Ellingson, L. L. (2008). Engaging crystallization in qualitative research: An introduction. Thousand Oaks, CA: SAGE.

Elliott, J. (1987). Educational theory, practical philosophy and action research. British Journal of Educational Studies, 35(2), 149-169.

Elliott, J. (1991). Action research for educational change. Philadelphia, PA: Open University Press. 
Elliott, J. (2009). Building educational theory through action research. In S. Noffke \& B. Somekh (Eds.), The SAGE handbook of educational action research (pp. 28-38). Thousand Oaks, CA: SAGE.

Fals-Borda, O. (1979). Investigating reality in order to transform it: The Colombian experience. Dialectical Anthropology, 4(1), 33-55.

Fals-Borda, O. (1985). Knowledge and people's power: Lessons with peasants in Nicaragua, Mexico and Colombia. New Delhi: Indian Social Institute.

Fals-Borda, O. (1991). Some basic ingredients. In O. Fals-Borda \& M. A. Rahman (Eds.), Action and knowledge: Breaking the monopoly with participatory action-research (pp. 3-12). New York, NY: Apex Press.

Fals-Borda, O. (2006). The north-south convergence: A 30-year first-person assessment of PAR. Action Research, 4(3), 351-358.

Feldman, A. (2007a). Validity and quality in action research. Educational Action Research, 15(1), 21-32.

Feldman, A. (2007b). Teachers, responsibility and action research. Educational Action Research, 15(2), 239-252.

Fine, M. (2008). An epilogue, of sorts. In J. Cammarota \& M. Fine (Eds.), Revolutionizing education: Youth participatory action research in motion (pp. 213-234). New York, NY: Routledge.

Flores-Kastanis, E., Montoya-Vargas, J., \& Suárez, D. H. (2009). Participatory action research in Latin American education: A road map to a different part of the world. In S. Noffke \& B. Somekh (Eds.), The SAGE handbook of educational action research (453-466). Thousand Oaks, CA: SAGE.

Freire, P. (1973). Education for critical consciousness. New York, NY: Continuum.

Garcia, A., Mirra, N., Morrell, E., Martinez, A., \& Scorza, D. (2015). The Council of Youth research: Critical literacy and civic agency in the digital age. Reading and Writing Quarterly: Overcoming Learning Difficulties, 31(2), 151-167.

Gergen, K. J., \& Gergen, M. M. (2008). Social construction and research as action. In P. Reason \& H. Bradbury (Eds.), The SAGE handbook of action research: Participative inquiry and practice (2nd ed., pp. 159-171). Thousand Oaks, CA: SAGE.

Giroux, H. A. (2006). Border pedagogy in the age of postmodernism. In H. A. Giroux \& C. G. Robbins (Eds.), The Giroux reader (pp. 47-66). Boulder, CO: Paradigm.

Glassman, M., \& Erdem, G. (2014). Participatory action research and its meanings: Vivencia, praxis, conscientization. Adult Education Quarterly, 64(3), 206-221.

Greenberg, I. A. (Ed.). (1974). Psychodrama: Theory and therapy. New York, NY: Behavioral Publications. 
Greenwood, D. J. (2015). An analysis of the theory/concept entries in the SAGE Encyclopedia of Action Research: What we can learn from action research in general from the encyclopedia. Action Research, 13(2), 198-213.

Greenwood, D. J. (2017). Action research. In M. Ciesielska \& D. Jemielniak (Eds.), Qualitative methodologies in organization studies: Volume I: Theories and new approaches (pp. 75-98). New York, NY: Palgrave Macmillan.

Greenwood, D. J., \& Levin, M. (2005). Reform of the social sciences and of universities through action research. In N. K. Denzin \& Y. S. Lincoln (Eds.), The SAGE handbook of qualitative research (3rd ed., pp. 43-64). Thousand Oaks, CA: SAGE.

Gullion, J. S., \& Ellis, E. G. (2014). A pedagogical approach to action research. Journal of Applied Social Science, 8(1), 61-72.

Habermas, J. (1984). The theory of communicative action, volume 1: Reason and the rationalization of society. Cambridge, MA: Polity Press.

Habermas, J. (2003). Truth and justification (B. Fultner, Trans.). Cambridge, MA: MIT Press.

Hammersley, M. (2004). Action research: A contradiction in terms? Oxford Review of Education, 30(2), 165-181.

Harkavy, I., \& Puckett, J. L. (2014). John Dewey. In D. Coghlan \& M. Brydon-Miller (Eds.), The SAGE encyclopedia of action research (Vol. 1, pp. 252-256). London, UK: SAGE.

Harvey, D. (2005). A brief history of neoliberalism. Oxford, UK: Oxford University Press.

Herzfeld, M. (2003). The unspeakable in pursuit of the ineffable: Representations of untranslatability in ethnographic discourse. In P. G. Rubel \& A. Rosman (Eds.), Translating cultures: Perspectives on translation and anthropology (pp. 109-134). Oxford, UK: Berg.

Hope, E. C., Skoog, A. B., \& Jagers, R. J. (2015). "It'll never be the white kids, it'll always be us": Black high school students' evolving critical analysis of racial discrimination and inequity in schools. Journal of Adolescent Research, 30(1), 83-112.

Jordan, S., \& Kapoor, D. (2016). Re-politicizing participatory action research: Unmasking neoliberalism and the illusions of participation. Educational Action Research, 24(1), 134-149.

Katsarou, E. (2017). The multi-paradigmatic character of contemporary educational action research: A promising perspective or an underlying threat? Educational Action Research, 25(5), 673-686.

Kemmis, S. (2008). Critical theory and participatory action research. In P. Reason \& H. Bradbury (Eds.), The SAGE handbook of action research: Participative inquiry and practice (2nd ed., pp. 121-138). Thousand Oaks, CA: SAGE.

Kemmis, S. (2010). What is to be done? The place of action research. Educational Action Research, 18(4), 417-427.

Kemmis, S., Heikkinen, H. L. T., Fransson, G., Aspfors, J., \& Edwards-Groves, C. (2014). Mentoring of new teachers as a contested practice: Supervision, support and collaborative selfdevelopment. Teaching and Teacher Education, 43, 154-164. 
Kemmis, S., \& McTaggart, R. (Eds.). (1988). The action research planner (3rd ed.). Victoria, Australia: Deakin University Press.

Kemmis, S., \& McTaggart, R. (2005). Participatory action research: Communicative action and the public sphere. In N. K. Denzin \& Y. S. Lincoln (Eds.), The SAGE handbook of qualitative research (3rd ed., pp. 559-603). Thousand Oaks, CA: SAGE.

Kemmis, S., \& Mutton, R. (2012). Education for sustainability (EfS): Practice and practice architectures. Environmental Education Research, 18(2), 187-207.

Kilgore, D. W. (2001). Critical and postmodern perspectives on adult learning. New Directions for Adult and Continuing Education, 2001(89), 53-61.

Kolb, D. A. (1984). Experiential learning: Experience as the source of learning and development (Vol. 1). Eaglewood Cliffs, NJ: Prentice-Hall.

Lacueva, A. (2000). Proyectos de investigación en la escuela: Científicos, tecnológicos y ciudadanos. Revista de Educación, 323, 265-288.

Langhout, R. D., \& Thomas, E. (2010). Imagining participatory action research in collaboration with children: An introduction. American Journal of Community Psychology, 46(1-2), 60-66.

Lather, P. (1986). Issues of validity in openly ideological research: Between a rock and a soft place. Interchange, 17(4), 63-84.

Lewin, K. (1946). Action research and minority problems. In G. W. Lewin (Ed.), Resolving social conflicts: Selected papers on group dynamics (pp. 34-46). New York, NY: Harper \& Row.

Li, X., Kenzy, P., Underwood, L., \& Severson, L. (2015). Dramatic impact of action research of arts-based teaching on at-risk students. Educational Action Research, 23(4), 567-580.

Lomax, P. (1995). Action research for professional practice. Journal of In-Service Education, 21(1), 49-57.

Lykes, M. B., \& Mallona, A. (2008). Towards transformational liberation: Participatory and action research and praxis. In P. Reason \& H. Bradbury (Eds.), The SAGE handbook of action research: Participative inquiry and practice (2nd ed., pp. 106-120). Thousand Oaks, CA: SAGE.

Lyotard, J.-F. (1984). The postmodern condition: A report on knowledge. Manchester, UK: Manchester University Press.

MacDonald, B., \& Walker, R. (1975). Case-study and the social philosophy of educational research. Cambridge Journal of Education, 5(1), 2-11.

MacIntyre, A. (2011). After virtue: A study in moral theory. London, UK: Bloomsbury.

Mackay, J., Birello, M., \& Xerri, D. (2018). ELT Research in Action: Bridging the gap between research and classroom practice. Kent, UK: IATEFL.

Maguire, P. (2006). Uneven ground: Feminisms and action research. In P. Reason \& H. Bradbury (Eds.), Handbook of action research. Participative inquiry and practice (1st ed., pp. 59-70). Thousand Oaks, CA: SAGE. 
Marshall, J., Coleman, G., \& Reason, P. (2017). Leadership for sustainability: An action research approach. New York, NY: Routledge.

Marx, K. (1977). Capital: A critique of political economy (Vol. III). Moscow, Russia: Progress Publishers.

Marx, K. (1991). Capital. In J. Adler Mortimer (Ed.), Great books of the western world (Vol. 56). Chicago, IL: Encyclopaedia Britannica.

Marx, K., \& Engels, F. (1978). The German ideology. In R. C. Tucker (Ed.), The Marx-Engels reader (2nd ed., pp. 146-200). New York, NY: W. W. Norton.

McComas, W. F., Reiss, M. J., Dempster, E., Lee, Y. C., Olander, C., Clément, P., . . Waarlo, A. J. (2018). Considering grand challenges in biology education: Rationales and proposals for future investigations to guide instruction and enhance student understanding in the life sciences. The American Biology Teacher, 80(7), 483-492.

McIntyre, A. (2008). Participatory action research. Thousand Oaks, CA: SAGE.

McKernan, J. (2008). Curriculum and imagination. Process theory, pedagogy and action research. New York, NY: Routledge.

McNiff, J. (1988). Action research: Principles and practice. Basingstoke, UK: Macmillan.

McTaggart, R. (1991). Action research: A short modern history. Victoria, Australia: Deakin University Press.

McTaggart, R. (1994). Participatory action research: Issues in theory and practice. Educational Action Research, 2(3), 313-337.

Miettinen, R. (2000). The concept of experiential learning and John Dewey's theory of reflective thought and action. International Journal of Lifelong Learning, 19(1), 54-72.

Mitra, D., \& McCormick, P. (2017). Ethical dilemmas of youth participatory action research in a democratic setting. International Journal of Inclusive Education, 21(3), 248-258.

Morales, J., Gendron, Y., \& Guénin-Paracini, H. (2014). State privatization and the unrelenting expansion of neoliberalism: The case of the Greek financial crisis. Critical Perspectives on Accounting, 25(6), 423-445.

Moreno, J. L. (1940). Mental catharsis and the psychodrama. Sociometry, 3(3), 209-244.

Morrell, E. (2006). Critical participatory action research and the literacy achievement of ethnic minority groups. 55th Annual Yearbook of the National Reading Conference, 55, 60-78.

Norris, N. (2012). Lawrence Alexander Stenhouse: An educational life. In J. Elliott \& N. Norris (Eds.), Curriculum, pedagogy and educational research. The work of Lawrence Stenhouse (pp. 7-48). London, UK: Routledge.

O’Neil, J., \& Marsick, V. J. (2007). Understanding action learning. New York, NY: AMACOM Books. 
Ospina, S., \& Anderson, G. (2014). The action turn. In D. Coghlan \& M. Brydon-Miller (Eds.), The SAGE encyclopedia of action research (pp. 18-21). Thousand Oaks, CA: SAGE.

Pauwels, L. (2015). "Participatory" visual research revisited: A critical-constructive assessment of epistemological, methodological and social activist tenets. Ethnography, 16(1), 95-117.

Pinter, A., \& Mathew, R. (2016). Children and teachers as co-researchers: A handbook of activities. London, UK: British Council.

Power, M. (1997). The audit society: Rituals of verification. Oxford, UK: Oxford University Press.

Rahman, M. A. (1985). The theory and practice of participatory action research. In O. Fals-Borda (Ed.), The challenge of social change (pp. 107-132). London, UK: SAGE.

Rahman, M. A. (2008). Some trends in the praxis of participatory action research. In P. Reason \& $\mathrm{H}$. Bradbury (Eds.), The SAGE handbook of action research: Participative inquiry and practice (2nd ed., pp. 49-62). Thousand Oaks, CA: SAGE.

Rappaport, J. (2017). Participation and the work of the imagination: A Colombian retrospective. In L. L. Rowell, C. D. Bruce, J. M. Shosh, \& M. M. Riel (Eds.), The Palgrave international handbook of action research (pp. 147-159). New York, NY: Palgrave Macmillan.

Reason, P., \& Bradbury, H. (2008). Introduction. In P. Reason \& H. Bradbury (Eds.), The SAGE handbook of action research: Participative inquiry and practice (2nd ed., pp. 1-10). Thousand Oaks, CA: SAGE.

Reid, C., \& Frisby, W. (2008). Continuing the journey: Articulating dimensions of feminist participatory action research (FPAR). In P. Reason \& H. Bradbury (Eds.), The Sage handbook of action research: Participative inquiry and practice (2nd ed., pp. 93-105). Thousand Oaks, CA: SAGE.

Romero, A., Cammarota, J., Dominguez, K., Valdez, L., Ramirez, G., \& Hernandez, L. (2008). “The opportunity if not the right to see": The social justice education project. In J. Cammarota \& M. Fine (Eds.), Revolutionizing education: Youth participatory action research in motion (pp. 131151). New York, NY: Routledge.

Rorty, R. (1991). Objectivity, relativism and truth: Philosophical papers (Vol. 1). Cambridge, UK: Cambridge University Press.

Rowell, L. L., Bruce, C. D., Shosh, J. M., \& Riel, M. M. (2017). Introduction. In L. L. Rowell, C. D. Bruce, J. M. Shosh, \& M. M. Riel (Eds.), The Palgrave international handbook of action research (pp. 1-14). New York, NY: Palgrave Macmillan.

Rowell, L. L., \& Hong, E. (2017). Knowledge democracy and action research: Pathways for the twenty-first century. In L. L. Rowell, C. D. Bruce, J. M. Shosh, \& M. M. Riel (Eds.), The Palgrave international handbook of action research (pp. 63-84). New York: Palgrave Macmillan.

Salleh, H. (2006). Action research in Singapore education: Constraints and sustainability. Educational Action Research, 14(4), 513-523.

Santoro Franco, M. A. (2005). Pedagogia da pesquisa-ação. Educação e Pesquisa, 31(3), 483502. 
Schwab, J. J. (1969). The practical: A language for curriculum. The School Review, 78(1), 1-23.

Shosh, J. M. (2017). Background and contexts. Introduction to background and contexts. In L. L. Rowell, C. D. Bruce, J. M. Shosh, \& M. M. Riel (Eds.), The Palgrave international handbook of action research (pp. 15-19). New York, NY: Palgrave Macmillan.

Siltala, J. (2013). New public management: The evidence-based worst practice? Administration \& Society, 45(4), 468-493.

Somekh, B. (2008). Action research. In L. M. Given (Ed.), The SAGE encyclopedia of qualitative research methods (Vols. 1-2, pp. 4-6). Thousand Oaks, CA: SAGE.

Somekh, B. (2010). The collaborative action research network: 30 years of agency in developing educational action research. Educational Action Research, 18(1), 103-121.

Stark, J. L. (2014). The potential of Deweyan-inspired action research. Education and Culture: The Journal of the John Dewey Society, 30(2), 87-101.

Stenhouse, L. (1967). Culture and education. London, UK: Thomas Nelson \& Sons.

Stenhouse, L. (1975). An introduction to curriculum research and development. London, UK: Heinemann.

Stenhouse, L. (1988). Artistry and teaching: The teacher as focus of research and development. Journal of Curriculum and Supervision, 4(1), 43-51.

Stenhouse, L. (1979). Research as a basis for teaching. In J. Elliott \& N. Norris (Eds.), Curriculum, pedagogy and educational research: The work of Lawrence Stenhouse (pp. 122136). London, UK: Routledge.

Stone, D. (2002). Policy paradox: The art of political decision making. New York, NY: W. W. Norton.

Street, B. (2012). New literacy studies. In M. Grenfell, D. Bloome, C. Hardy, K. Pahl, J. Rowsell, \& B. Street (Eds.), Language, ethnography, and education: Bridging new literacy studies and Bourdieu (pp. 27-49). New York, NY: Routledge.

Swantz, M. L. (2008). Participatory action research as practice. In P. Reason \& H. Bradbury (Eds.), The SAGE handbook of action research: Participative inquiry and practice (2nd ed., pp. 31-48). Thousand Oaks, CA: SAGE.

Tandon, R. (2017). Participatory research in Asia (PRIA). In L. L. Rowell, C. D. Bruce, J. M. Shosh, \& M. M. Riel (Eds.), The Palgrave international handbook of action research (pp. 441454). New York, NY: Palgrave Macmillan.

Torre, M. E. (2009). Participatory action research and critical race theory: Fueling spaces for nos-otras to research. The Urban Review, 41(1), 106-120.

Tripp, D. (1987). Action research and professional development. In P. Hughes (Ed.), Better teachers for better schools (pp. 201-222). Victoria: The Australian College of Education.

Van Lier, L. (1994). Action research. Sintagma, 6, 31-37. 
Villacañas de Castro, L. S. (2016). Critical pedagogy and Marx, Vygotsky and Freire: Phenomenal forms and educational action research. New York, NY: Palgrave Macmillan.

Villacañas de Castro, L. S. (2019). Deweyan democracy, neoliberalism, and action research. Studies in Philosophy and Education, 39(1), 19-36.

Wamba, N. (2011). Developing an alternative epistemology of practice: Teachers' action research as critical pedagogy. Action Research, 9(2), 162-178.

Wang, C., \& Burris, M. A. (1997). Photovoice: Concept, methodology, and use for participatory needs assessment. Health Education \& Behavior, 24(3), 369-387.

Weber, M. (1946). Essays in sociology. Oxford, UK: Oxford University Press.

Wicks, P. G., Reason, P., \& Bradbury, H. (2008). Living inquiry: Personal, political and philosophical groundings for action research practice. In P. Reason \& H. Bradbury (Eds.), The SAGE Handbook of action research: Participative inquiry and practice (2nd ed., pp. 14-30). Thousand Oaks, CA: SAGE.

Zeichner, K. M., \& Noffke, S. E. (2001). Practitioner research. In V. Richardson (Ed.), Handbook of research on teaching (4th ed., pp. 298-332). Washington, DC: American Educational Research Association.

Zeni, J. (1998). A guide to ethical issues and action research. Educational Action Research, 6(1), 9-19.

\section{Related Articles}

Participatory Action Research in Education

Pacific Research Methodologies and Relational Ethics

Action Research 